\title{
LOCKDOWN: A COMMENTARY
}

\begin{abstract}
The Collins dictionary has elected lockdown as its word-of-the-yearn 2020. Defined as "the imposition of stringent restrictions on travel, social interaction and access to public spaces", decided by governments "to mitigate the spread of COVID-19", for Collins' lexicographers "lockdown" took the top spot because it is a unifying experience for billions of people across the world, who have had, collectively, to play their part in combating the spread of the virus. Faced with the unknown of a brand-new virus, governments all over the world reacted in a rather familiar way, by suspending the normal flow of social life through the implementation of measures that are usually categorised as a state of exception. This article is a commentary that aims at placing the practice of lockdown (as a governmental administrative measure) in the context of the theory of state and government. To the extent that emergencies are always revelatory, this paper will argue that the state of exception - of which the lockdown is a sub-category - in displaying state's sovereign power is exposing the radical impotence in which it is grounded, and from which it takes its ultimate meaning and function.
\end{abstract}

Keywords: lockdown, COVID-19, pandemic, state of exception, security.

\section{LOCKDOWN: KOMENTARZ}

Streszczenie. Słownik Collinsa wybrał lockdown jako swoje słowo roku 2020. Zdefiniowane jako „nałożenie surowych ograniczeń na podróże, interakcje społeczne i dostęp do przestrzeni publicznej”, o których zadecydowały rządy „w celu złagodzenia rozprzestrzeniania się COVID-19”; dla leksykografów Collinsa lockdown zajął pierwsze miejsce, ponieważ jest to jednoczące doświadczenie dla miliardów ludzi na całym świecie, którzy musieli wspólnie odegrać swoją rolę $\mathrm{w}$ walce $\mathrm{z}$ rozprzestrzenianiem się wirusa. W obliczu nieznanego, zupełnie nowego wirusa, rządy na całym świecie zareagowały w dość znany sposób, zawieszając normalny tok życia społecznego poprzez wdrożenie środków, które zwykle zalicza się do stanu wyjątkowego. Niniejszy artykuł jest komentarzem, który ma na celu umieszczenie praktyki lockdownu (jako rządowego środka administracyjnego) w kontekście teorii państwa i rządu. W zakresie, w jakim sytuacje nadzwyczajne są zawsze odkrywcze, artykuł ten będzie argumentował, że stan wyjątkowy - którego podkategorią jest zamknięcie - w eksponowaniu suwerennej władzy państwa obnaża radykalną niemoc, w której jest ugruntowany i z której bierze swoje ostateczne znaczenie i funkcję.

Słowa kluczowe: lockdown, COVID-19, pandemia, stan wyjątkowy, bezpieczeństwo.

*University of Kent, Uczelnia Lazarskiego; g.g.fusco-3@kent.ac.uk 


\section{INTRODUCTION}

At first, the virus invaded our bodies, then it attacked our already sick polities making the megamachine of capital slow down dramatically; and finally, it has colonised the psycho-sphere (Berardi 2020), populating our imaginary with terrifying images (the invisible enemy; the death of loved ones; engulfed intensive care units; the unknown economic shock, which we are told 'this time will be different"). As an epochal event the pandemic marks an irreversible cognitive threshold in the twenty-first century, which is pushing us to look to the past and the future with different eyes. Perpetually exposed to the infodemic spectacle of the contagion, our everyday parlance has been invaded by words whose use was certainly not common, and until recently limited to the specialisms of specific scientific sectors. Coronavirus, pandemic, herd immunity, contact tracing, quarantine, self-quarantine, self-isolation, social distancing, super-spreader: these are some of the words that entered abruptly our lexicon; hopefully not permanently.

Among this plethora of terms, the Collins dictionary has elected lockdown as its word-of-the-year 2020. Defined as "the imposition of stringent restrictions on travel, social interaction and access to public spaces", decided by governments "to mitigate the spread of COVID-19", for Collins" lexicographers "lockdown" took the top spot because it is a unifying experience for billions of people across the world, who have had, collectively, to play their part in combating the spread" of the virus. ${ }^{1}$ Faced with the unknown of a brand-new virus, governments all over the world reacted in a rather familiar way, by suspending the normal flow of social life through the implementation of measures that are usually categorised as a state of exception.

Locked down in the quasi-monastic (Coccia 2020) singularity of our own existence, we are witnessing the strange revival of the state's authority. In an ironic twist, the vituperate entity that we-the-moderns call state - whose death has been celebrated tragicomically on countless occasions - is back at the centre of the stage, as the only certain shelter remained in a world devastated by economic, ecologic, and sanitary tragedies. Blessed are the governments caring for the health of the population, and holy are the exceptions made in the name of our safety. There are not rights immune to be sacrificed for the sake of the security of the population - if anything, this the lesson we learnt with two decades of war on terror.

Forgetful of the fact that the state in its connivance with the capital played a central role in producing the tragedy we are living, we remain jammed in the magic of the spectacle of the pandemic (whose reality, of course, should not be doubted). And in such re-enchantment of state's institution, contesting the exception, and the ethical conundrums of the contagion appear as the ultimate

\footnotetext{
${ }^{1}$ https://www.collinsdictionary.com/it/woty [Accessed: 15 February 2020].
} 
blasphemy: that of the negationists (Agamben 2020b). So it goes. Even when faced with the blatant irrationality of some emergency measures enacted by governments, we are stuck on the binary option of being either with the reason of the good state and the good science or with the ethos of conspiracy; either with the (Malthusian) human natural selection or with the herd of good citizens practising social distancing for "protecting themselves and the others." The pandemic produced a strange paradox: it has enlarged our everyday vocabulary while reducing at the same time the space for critical thinking.

But even in impending catastrophes, we should never refrain from questioning our forms of life and the strategies governmental powers implement to shape them. Hopefully, a state of exception will save us. But the post-pandemic world that is emerging inevitably raises the question of the risks entailed in prolonged crises and the instruments that are usually deployed to solve them. Indeed, as Agamben poignantly asked: what do human relationships become in a country that habituates itself to live in this way for who knows how long? And what is a society that has no value other than survival (Agamben 2020, 26)? The risk is that the fetish of security on which the very idea of the modern state's power and authority have been built assumes inexorably the form of an iron cage, in which the preservation of life coincides with the renunciation of what makes life bearable, and the very possibility of thinking change and a happier life becomes overshadowed by the concerns for never-ending security.

\section{IMPOTENCE}

Exceptional circumstances have always a revealing potential. ${ }^{2}$ The lockdown, with its suspension of rights and the alteration of our daily gestures, reveals in a way the nature and essence of the state's power. It is not surprising, though, that in the enormous body of literature on the pandemic the name of Hobbes is a recurring one (Santi 2020; Iacob 2020; Hunt Bottin 2020; Lamola 2020). Perhaps, there is no other product of the human mind that has captured the essence of the state's authority more effectively than the Leviathan. Hobbes famously placed at the core of modern politics a fundamental bargain between security and absolute liberty: a kind of pact with which humans fearing for the preservation of their own life decide to give away part of their unbounded freedom for the sake of their security, which is conversely placed in the hands of the sovereign. "The office of the sovereign" we read in chapter XXX of the Leviathan,

${ }^{2}$ As Schmitt - paraphrasing Kierkegaard (1983) - wrote in a notorious passage of Political Theology: "The exception is more interesting than the rule. The rule proves nothing; the exception proves everything: It confirms not only the rule but also its existence, which derives only from the exception. In the exception the power of real life breaks through the crust of a mechanism that has become torpid by repetition" (Schmitt 2005, 15). 
consisteth in the end, for which he was trusted with the sovereign power, namely the procuration of the safety of the people; to which he is obliged by the law of nature, and to render an account thereof to God, the author of that law, and to none but him. But by safety here, is not meant a bare preservation, but also all other contentments of life, which every man by lawful industry, without danger, or hurt to the commonwealth, shall acquire to himself. (Hobbes 1996, 222)

The salus populi is here symmetrical with the fundamental purpose of the construction of state power. "The final cause, end, or design of men [...] in the introduction of that restraint upon themselves" Hobbes writes "is the foresight of their own preservation, and of a more contented life thereby" (Hobbes 1996, 111). The monopoly of legal violence, inscribed in the very functioning of sovereign power, is thus a desirable side effect for the sake of our security; of our salus.

But what is security? What problem modern politics aims to address in putting security at the centre of its own legitimisation? Physical integrity and our right to life, living out of the misery and precarity of war; but also, the contentment that makes life worth to be lived, the protection and security of human labour: these are the problems security usually addresses. Security is the certainty that our form of life is grounded on rational structures or truths that allow us to foresee what will come next; it is the belief that faced with the contingency of natural and human events, scarcity will be governed, and damages (economic, physical but also moral) will be compensated by specific institutions. The modern political principle of security responds to a general social-political demand to limit uncertainty, the aleatory; it is in a sense the translation into the political vocabulary of the idea of a human dominion/management of contingency (and the world) so dear to the canon of modernity.

As Foucault has argued, the problem of security and the emergence of its political/institutional apparatus appears on the "the philosophical horizon" of the category of misfortune, which encompasses all those factors - like bad weather, drought, ice, and ultimately war - that are out of "one's control" (Foucault 2009, 31). Bad fortune is both a recognition of impotence and a "political, moral and cosmological concept" (ibid). Due to their defective nature, humans are left in a state of constant insecurity; and the misfortunes that gnaw people and threaten the stability of polities are signs delivered by (divine) providence that something is inherently wrong with how affairs are conducted and need to be changed. From natural catastrophes to human's malice, the security that state's potency must grant is grounded on the substantial impotence of the contingent. And the art of government, as Machiavelli famously argued, consists of the application of rules and strategies that statesmen should adopt to limit, control, and turn in favour their impotence and fortune (Machiavelli 1988). And it is against this background that the modern government (as an art) and state's institutions emerged and developed into a form of administration of security; helped by the constant improvement of technology and sciences such as statistics, demography, economy, and medicine. 
In its polysemy, the concept of security refers to the strategies through which state's power aims at making life and the world at large predictable and manageable, through the creation of specific apparatuses, laws, procedures, and competencies (Ventura 2020, 97). "The mechanism of security", Foucault claims, "making use of some instruments of prescription and prohibition" responds "to a reality in such a way that [...] nullifies it, or limits, checks or regulates it" (Foucault 2009, 47). Faced with the incommensurability of the contingent (of providence) the apparatus of security does not aim at transforming the nature of "events"; but tries to nullify, regulate and limits their effects. Indeed, the logic underpinning security is not much the creation/ imposition of order through the elimination of contingency, rather - as Agamben points out - it consists of guiding "disorder" (Agamben 2001, 23), that is letting things "happen" and assessing/managing risks and collateral effect.

The creation of the State-Leviathan, thus, inaugurated a process of world ordering, intertwined with capitalism modernisation, materialised in the political form of the nation-state, governmentality, and juridification (bureaucratisation) of the whole of reality. The actual/ideal function of these apparatuses necessitated on the one hand the production of a class of functionaries able to administer a growing number of things, events, and subjects (the so-called elites) (Ventura 2020, 97-98); and on the other hand, the substantial depoliticization of many of the sphere of human individual and social life whose administration is isolated from majoritarian political intervention and delegated to the governmental bodies, with the consequent creation of docile depoliticised subjectivities.

As Foucault maintains, one of the greatest innovations of the modern form of political power is the "emergence of population as an economic and political problem: population as wealth, population as manpower or labor capacity, population balanced between its own growth and the resources it commanded" (Foucault 1998, 25). For the Modern state, the target of the government's apparatus was not the individual not even the "people", but the population "with its specific phenomena and its peculiar variables: birth and death rates, life expectancy, fertility, state of health, frequency of illnesses, patterns of diet and habitation" (Foucault 1998, 25). The population, Foucault maintains, is an assemblage of bodies trapped in a system of government and disciplinary regulation; it is a passive subject/object whose existence depends on a specific way of observing the multitude of individuals composing the body of the state. "The population is not a primary datum" but is an entity "dependent on a series of variables", subject to manipulation and management (Foucault 2009, 71). The object population, thus, is not something given, rather is the product of a calculating analytic strategy. The population, Foucault claims, appears as a "kind of thick natural phenomenon" composed of a "set of elements in which we can note constants and regularities" (Foucault 2009, 71) which goes to produce a sort of harmonic framework in which it is possible to identify tendencies that could be made the target of intervention for the supposed benefit of all. 
The production of security that is at stake in the constitution of modern states determines a substantial form of depoliticization of the body politic. The subjectobject of governmental practices that goes under the name of population is not capable of self-determination but is a passive subject. Foucault expresses this by distinguishing between "people" and "population." With the development of political economy and the modern theory of government, "the population covers the old notion of people" (Foucault 2009, 43). The people become regarded as

those who conduct themselves in relation to the management of the population, at the level of the population, as if they were not part of the population as a collective subject-object, as if they put themselves outside of it, and consequently the people are those who, refusing to be the population, disrupt the system. [...] the people are generally speaking, those who resist the regulation of the population, who try to elude the apparatus by which the population exists, is preserved, subsists at an optimal level. (Foucault 2009, 43-44)

Differently from the people, the population is not a collective subject established by a (social) contract or a decision towards unity. The population as "subject" - that orients itself and is oriented through the action of government - is not an entity capable of any form of activity: "if one says to a population do this", Foucault points out, "there is not only no guarantee that it will do it, but also there is quite simply no guarantee that it can do it" (Foucault 2009, 71). Despite being composed of the same substance - the collective lives of the members of a given community - people and population are the product of different forms of subjectivation: the latter is established through the implementation of security mechanisms (what Foucault termed police), the former instead pretend to be an active force exercising a certain power over itself, declaring for itself the faculty of self-determination, opposing to the constituted order, the will to escape the tangles of governmental practices.

Ingrained in the principle of security, the modern state finds its legitimacy in the biocontainment and safeguard of its living substance - in the immunisation of the body politic from the contingency of human and natural events. The well-functioning of the state's apparatuses of security, with its disciplines and regulations, bureaucracy, commissars, and special counsels, is indirectly proportional to the possibility of resisting and contesting the leviathan. This is, in other words, what Foucault intended by distinguishing people and population. Implicit in the paradigm of security is the idea that the salus can only be achieved through a calculated limitation of the contingent; that is the delusional technicalbureaucratic transformation of fortune in risk. ${ }^{3}$ And what the pandemic has exposed once more is that the administrative governance of the modern state

${ }^{3}$ In the last few decades, the concept of risk has become a "sociological" category in its own right. The literature on the field has grown significantly and it is right now more than vast. Perhaps, the more notorious efforts are Beck (1992) and Luhmann (1993). For an overview on the sociology of risk see: Roser et al. (2012). 
is indeed oriented and governed by what is ultimately ungovernable (Di Cesare 2020, 29). But what happens when contingency starts cracking into the gears of the machines of state's power? What happens when the machina machinarum falters and is not capable anymore to grant the security of the state?

\section{EXCEPTION}

In its canonical definition lockdown pertains to all those kind of emergency measures that countries usually implement to face and manage the contingent, which scholars often classify as a "state of exception." The state of exception is what the law provides to adapt social and political systems to unpredictable threats. It is worth noting that the modern doctrine of the state of exception is substantially rooted in the context of war and the experience of being besieged. Legally speaking, the state of exception is a crisis reaction mechanism which alters the division/balance of powers and suspends certain liberties to restore as quickly as possible a condition of normality. The war metaphors that have been seldom used to depict the pandemic are in a sense the logical discursive companion to the application of specific measures thought for wartime: they tend to create the semiotic atmosphere to make the exception legitimate (Fusco 2020, 16).

The language with which the law is guiding legitimate authorities towards their own self-alteration (or suspension) is perhaps one of the most controversial aspects of emergency powers. Constitutional texts often use terms like alarm, ${ }^{4}$ case of necessity and urgency, ${ }^{5}$ tension; ${ }^{6}$ the language with which the law tries to grasp the exceptional case is varied, flexible and open to diverse interpretations. Indeed, the very definition of emergency is not immune to controversies and alternative/opposed interpretation. The indeterminacy of the legal language ${ }^{7}$ inherent to the doctrine of the state of exception allows potentially to implement the same measures to challenge very different emergencies. ${ }^{8}$ But this is somehow

${ }^{4}$ Spanish Constitution, art. 116.

${ }^{5}$ Italian Constitution, art. 77.

${ }^{6}$ Basic Law for the Federal Republic of Germany, art. 80a.

${ }^{7}$ Of course the indeterminacy of legal language is not limited to the state of exception. The "indeterminacy thesis" is part of the golden age of Critical Legal Theory: see Tushnet (1996).

${ }^{8}$ It is worth nothing here that in this paper the terms emergency and exception are used as synonyms. I am aware that this might appear to some as controversial. Last year the famous Italian jurist and former president of the Italian Constitutional court Gustavo Zagrebelski, in the volume Il Mondo dopo la Fine del Mondo (2020), distinguished between "emergency" as something limited in time and regulated by law, from the "exception" as a form of dictatorial government that suspends and eventually transforms without guarantees the law. As Agamben as suggested this is nothing other than a re-framing of Schmitt's distinction between commissar and sovereign dictatorship and therefore emergency is somehow still exception (Agamben 2020a). If we look to the history of the emergence of the state of exception, as a legal doctrine, we could see that it refers in 
a consequence of the very nature of the function of the exception as a legal object. As Alexander Hamilton has argued, the law in providing for itself the means to deal with emergencies should take into account that

the circumstances that may endanger national safety are infinite and unpredictable; and for this reason, no constitutional mechanism is able to frame and provide for it, since it is impossible to foresee or to define the extent and variety of national exigencies, and the correspondent extent and variety of the means which may be necessary to satisfy them. The circumstances that endanger the safety of nations are infinite, and for this reason, no constitutional shackles can wisely be imposed on the power to which the care of it is committed. This power ought to be coextensive with all the possible combinations of such circumstances; and ought to be under the direction of the same councils, which are appointed to preside over the common defense. (Hamilton 2008, 114)

This peculiar elasticity of the language of emergency powers is in a way the reflex of the very impossibility of grasping contingency at a denotative level. One could also argue that the state of exception formulates in legal language such substantial impotence in foreseeing the infinite threats for the safety of nations, providing in this way state's power with very flexible instruments, which permits in the end to alter the law - to suspends rights and the normal balance of state's powers - in very different situations irrespective of the severity of the type of threats (Fusco 2020, 17).

Looking to the lockdown through the lenses of the state of exception should not lead us to reach the extreme conclusion that democracies all over the world are in a way slipping into dictatorships. Rather it is an indicator that once more, faced with an emergency - fictitious or real - the standard governmental reaction consists in the intensification of disciplinary functions and governmental practices, usually obtained through a suspension of specific rights, and the alteration of the normal balance of state powers and the delegation of a broader authority to the executive. Implicit in the very idea of the state of exception is the assumption that a legal system works properly only in normal times and that the solution of an urgent threat cannot be hindered by standard legal procedures. But, if anything, the contemporary forms of states of exception that have been implemented in the last two decades, especially in the context of the "war on terror", show us that the sovereign exception, in its absolute essence, becomes gradually less visible (and legible): it has become embedded in the administrative practices of offices and bureaucratic apparatuses. To the extent that the exception in its modern form has become gradually normalised and regulated, the operative agents are right now the functionaries, the bureaucrats, the gendarme. The sovereign exception has been subsumed in the interstices of the rule of law, and its re-emergence in the moment of the pandemic exception, with its plethora of laws

its modern version to all those provisions, part of constitutional law or legislations, regulation the administration of emergency powers. State of emergency and state of exception, thus, should be considered as to signifiers for the same signified. 
and regulation altering the normal flow of law, is revealing of its change in form but not in substance.

Carl Schmitt expressed the revelatory essence of the exception via an analogy with the miracle. "The exception in jurisprudence" he writes "is analogous to the miracle in theology. Only by being aware of this analogy can we appreciate the manner in which the philosophical ideas of the state developed in the last centuries" (Schmitt 2005, 36). As the miracle - according to its canonical theological understanding - is an infringement of the natural eternal laws, product of god's almighty power, the exception becomes the moment in which sovereignty reveals its true nature. Such an analogy serves indeed quite effectively Schmitt's theorisation of a political (but also juridical) theology. However, it also brings about the vexata quaestio of the accommodation of sovereign absolute power within the framework of the constituted order.

As the centuries-long theological debate over the potentia dei shows, the recognition of the legitimate existence of miracles produces a series of paradoxes and questions of difficult solution. In Christian theology, the omnipotent "god of the Nicene creed is free to choose which world to create", among the many possible worlds; he can intervene in the created world, upsetting its rule, to which he is not bond (Randi 1987, 3). However, the immutable, perfect god cannot but act eternally towards some good. A god that does not realise the best of the possible world, in this perspective, would contradict its perfection, it would be a god without the perfection of a god (Randi 1987, 3-4). But again, a god (or a sovereign) whose omnipotence remains ultimately limited by its own creation would be a perfect but impotent god. Much like the exception, the miracle is a manifestation of the absolute power of god who can legislate in what way it prefers, even against the ordo naturae he has created, but by doing so he renders manifest the substantial imperfection of its creational potency. ${ }^{9}$

\section{STAY HOME}

As Foucault argued in his research on the emergence of biopower, for the modern treatment of epidemics the relation inside-outside, typical of the disciplinary management of otherness, is inverted. Established as a form of containment of the plague in the $15^{\text {th }}$ century, ${ }^{10}$ the quarantine aims at mitigating and controlling the spread of a disease, by immunising the population, not

${ }^{9}$ Eventually, this paradox found a systematisation in the elaboration of the distinction between potentia absoluta and potentia ordinata Dei. But the plethora of contrasting interpretations that such a crucial theological and political distinction has been subjected to is a further symptom that the conundrums of God's (and sovereign) power are still intact. On this issue see: Randi 1987; Ojakangas 2012; Traversino 2018.

${ }^{10}$ See: D'Abramo et al. (2021). 
through a grand act of margination (and separation) of those infected, but through their inclusion, control and tracing (Foucault 2003, 43-46). For this form of administration of epidemics, the threat is not coming from the outside but is nestled among us all (and indeed Foucault pointed out how the quarantine has been usually imposed in towns in which the plague had already broken out); we must isolate from the other because both us and the other are a threat to the survival (salus) of the population. The imposition by decree of social distancing, the walling of our singularity, produces nothing less than the abolition of the other (De Cesare 2020, 59), in exchange for individual security and immunity for all.

But the imposition of distance, our locked-down existence, supported by repetitive slogans - like "stay home" - is rather insidious. It produces a false sense of solidarity, reciprocal accountability, and empowerment, which covers the same forms of exclusion and cancellation of the other as a plague spreader; but with the illusion of heroically renouncing to our liberties for the common good, all adorned by the hideous greetings to the ill-fated who remain exposed to the virus to work for the sake our health. Implicit in the "stay home" is the substantial impotence of state power in facing the pandemic. As the slogan adopted by the UK government flaunted at every press conference says "stay home, protect the NHS, save lives", what we are safeguarding by locking up ourselves at home is not immediately our life or health, but the state's capacity of taking care of it (protect the NHS). And perhaps this is the essential meaning of the Brocard salus populi suprema lex. As Kant suggested in his Anthropology from a Pragmatic Point of View, such a dictum

does not mean that the physical well-being of the community (the happiness of the citizens) should serve as the supreme principle of the state constitution [...] The dictum says only that the rational well-being, the preservation of the state constitution once it exists, is the highest law of a civil society as such; for society endures only as a result of that constitution. (Kant 2006, 236)

In his sparse and admittedly controversial considerations on the pandemic and the consequences of the global state of exception, Agamben highlighted a crucial ethical problem. It is right now evident that the protection of our bare life at all costs, is transforming our lived existence into something that has departed from what we have usually valued as human. It is obvious, Agamben writes, that we "are disposed to sacrifice practically everything - the normal conditions of life, social relationships, work, even friendships, affections, and religious and political convictions - to the danger of getting sick. Bare life - and the danger of losing it - is not something that unites people, but blinds and separates them" (Agamben 2020, 26). Hopefully, social distancing implemented in its harsher form will save us from the current pandemic; but of course, this could lead to the gravest of the perils: the renunciation to what makes human life bearable and the emergence of mere biological life as a permanent living condition. But, as 
Agamben asks: what is a society that has no value other than survival? (Agamben 2020, 26). Perhaps as never before, in the current pandemic, our bare life appears as the proper subject of security and state power. The task before us is to keep the memory of this alive, especially at the moment in which the catastrophe seems to drift slowly into the past.

\section{BIBLIOGRAPHY}

Agamben, Giorgio. 2001. "Security and Terror." Theory \& Event 5(4). https://doi.org/10.1353/ tae. 2001.0030

Agamben, Giorgio. 2020. A che punto siamo? L'Epidemia come politica. Macerata: Quodlibet.

Agamben, Giorgio. 2020a. "Stato di Eccezione e Stato di Emergenza." Quodlibet, July 30, 2020. https://www.quodlibet.it/giorgio-agamben-stato-di-eccezione-e-stato-di-emergenza [Accessed: 17 June 2021].

Agamben, Giorgio. 2020b. "Due vocaboli infami." Quodlibet, July 10, 2020. https://www.quodlibet. it/giorgio-agamben-due-vocaboli-infami [Accessed: 17 June 2021].

Beck, Ulrich. 1992. The risk society. Towards a new modernity. London: Sage.

Coccia, Emanuele. 2020. "Reversing the New Global Monasticism." Semester, April 21, 2020. https://fallsemester.org/2020-1/2020/4/17/emanuele-coccia-escaping-the-global-monasticism [Accessed: 15 February 2021].

D’Abramo, Flavio. Giulia Gandolfi. Gerardo Ienna. Pietro Daniel Omodeo. Charles Wolfe. 2021. "Political Epistemology of Pandemic Management." MeFiSto. Medicina Filosofia Storia.

De Cesare, Donatella. 2020. Virus sovrano? L'Asfissia capitalistica. Torino: Bollati Boringhieri.

Foucault, Michel. 1998. The History of Sexuality. Vol. 1: An Introduction. Translated by R Hurley. New York: Penguin.

Foucault, Michel. 2003. Abnormal: Lectures at the Collège de France, 1974-1975. Translated by Graham Burchell. New York: Picador.

Foucault, Michel. 2009. Security, Territory, Population: Lectures at the Collège De France, 19771978. Translated by Graham Burchell. Basingstoke: Palgrave Macmillan.

Fusco, Gian Giacomo. 2020. "Exception, Fiction, Performativity." In States of Exception: Law, History, Theory. 15-33. Edited by Gian Giacomo Fusco, Cosmin Cercel, Simon Lavis. Abingdon-New York: Routledge. https://doi.org/10.4324/9780429022296-1

Hamilton, Alexander. 2008. The Federalist Papers. Oxford: Oxford University Press.

Hobbes, Thomas. 1998. Leviathan. Edited by J.C.A. Gaskin. Oxford: Oxford University Press.

Hunt Botting, Eileen. 2020. "A novel (coronavirus) reading of Hobbes's Leviathan." History of European Ideas. 47(1): 33-37. https://doi.org/10.1080/01916599.2020.1792059

Iacob, Anisia. 2020. "The Question of Technology and Media in the Current Pandemic." Saeculum 50(2): 11-18.

Kant, Immanuel. 2006. Anthropology from a Pragmatic Point of View. Translated by Robert B. Louden. Cambridge: Cambridge University Press.

Kierkegaard, Søren. 1983. Fear and Trembling: Repetition. Translated by Howard V. Hong. Princeton: Princeton University Press.

Lamola, M. John. 2020. "Thomas Hobbes in the Time of Coronavirus.” Social Epistemology Review and Reply Collective 9(4): 72-75.

Luhmann, Niklas. 1993. Risk: A Sociological Theory. Berlin: Walter de Gruyter. 
Ojakangas, Mika. 2012. "Potentia absoluta et potentia ordinata Dei: on the theological origins of Carl Schmitt's theory of constitution." Continental Philosophy Review 45: 505-517. https:// doi.org/10.1007/s11007-012-9233-x

Randi, Eugenio. 1987. Il Sovrano e l'Orologiaio. Due immagini di Dio nel dibattito sulla «Potentia absoluta» fra XIII e XIV secolo di Eugenio Randi. Firenze: La Nuova Italia.

Roeser, Sabine. Rafaela Hillerbrand. Per Sandin. Martin Peterson. Eds. 2012. Handbook of Risk Theory Epistemology, Decision Theory, Ethics, and Social Implications of Risk. Dordrecht: Springer. https://doi.org/10.1007/978-94-007-1433-5

Santi, Raffaella. 2020. "Politics and Salus Populi: Hobbes and the Sovereign as Physician of the State." Philosophy Study 10(11): 693-702. https://doi.org/10.17265/2159-5313/2020.11.003

Schmitt, Carl. 2005. Political Theology. Four Chapter on the Concept of Sovereignty. Translated by George Schwab. Chicago: The University of Chicago Press. https://doi.org/10.7208/ chicago/9780226738901.001.0001

Traversino Di Cristo, Massimiliano. 2018. "The Classic Age of the Distinction between God's Absolute and Ordered Power." Franciscan Studies 76(1): 207-266. https://doi.org/10.1353/ frc. 2018.0007

Tushnet, Mark. 1996. "Defending the Indeterminacy Thesis.” Quinnipiac Law Review 16: 339-356. Ventura, Raffaele Alberto. 2020. Radical Choc. Ascesa e caduta dei competenti. Torino: Einaudi.

Zagrebelsky, Gustavo. 2020. Il Mondo dopo la fine del Mondo. Roma-Bari: Laterza.

\section{Legal Acts}

Basic Law for the Federal Republic of Germany. https://www.btg-bestellservice.de/pdf/80201000. pdf [Accessed: 17 June 2021].

Italian Constitution. https://www.senato.it/documenti/repository/istituzione/costituzione_inglese. pdf [Accessed: 17 June 2021].

Spanish Constitution. https://www.boe.es/legislacion/documentos/ConstitucionINGLES.pdf [Accessed: 17 June 2021]. 